\title{
PALEOGRAFÍA ARAGONESA DE LA ALTA EDAD MEDIA ANTERIOR AL AÑO 1137
}

El futuro reino de Aragón es en sus orígenes un condado dependiente del reino de Pamplona, con escasa presencia cultural, salvo la de algún centro monástico excepcional como será San Pedro de Siresa que, según el viajero cordobés San Eulogio, contaba en el siglo IX con un centenar de monjes para atender a viajeros peregrinos a través del puerto del Palo, y atesoraba una excelente biblioteca. Apenas se sabe de otros centros, posibles núcleos de cultura escrita como los de los Santos Adrián, Natalia y María de Sasabe, que fue sede del obispado más antiguo aragonés, el de San Salvador de Puyó, el de San Martín de Cillas en el rio Veral, San Martín de Cercito en el rio Aurín; al sur del río Aragón solamente existe el monasterio de los Santos Julián y Basilisa de Navasal, que con el tiempo se integraría en el de San Juan de la Peña.

A la otra orilla del Gállego, otros dos monasterios parece que fueron asiento cultural y tuvieron sus escritorios: los de San Victorián de Asán, con lejanos contactos con Italia, o San Andrés de Fanlo, del que aún ha llegado testimonio documental de una excelente biblioteca que guardaba en el siglo XI.

En todos ellos se mantuvo la tradición visigoda. Pero las dependencias respecto de Pamplona, la ulterior ultrapirenaica, la presencia de mozábares refugiados venidos del valle medio del Ebro (ejemplo los eremitas Voto, Félix, Benedito y Marcelo, especialmente en el área de San Juan de la Peña), nuevas aperturas hacia tierras francas bajo Sancho el Mayor, llegada de artesanos y mercaderes a la capitalidad de Jaca desde 1077, la implantación de monjes cluniacenses, las cruzadas francas bajo Sancho Ramírez, casamientos con damas ultrapirenaicas o italianas de los primeros reyes de Aragón, el cambio de rito litúrgico, las legacías romanas, la introducción de reglas canónicas agustinianas, etc. etc. cambiarán las condiciones culturales e influirán en la evolución de la escritura.

Esta variedad de influencias, y sobre todo la sucesiva incorporación al reino de Aragón de tierras reconquistadas, conclusa a fines del siglo XII, hacen de este reino un conjunto de regiones insolidarias, sólo unidas por un rey; y la prueba palpable de ello será la tarjeta de visita con que se intitula en sus documentos el príncipe Ramón Berenguer IV como rey consorte de Aragón, dominante en Aragón, Sobrarbe, Ribagorza, Zaragoza, Tarazona y Catalayud. 
¿Cuál es el legado paleográfico de Aragón en la alta edad media hasta la Unión con el condado de Barcelona? Simplemente: la persistencia de la tradición visigoda y el mantenimiento muy prolongado de las grafías visigóticas.

Los testimonios epigráficos afirman lo que las escrituras sobre pergamino nos muestran: tipos capitales clásicos, con alguna grafía uncial. Dos ejemplos: uno de 1072, las inscripciones de consagración de la iglesita de Santa María de Iguacel, y otro de 1095, la lauda sepulcral de la jamba de entrada a la fortaleza de Loarre, son interesantes; además ambos están datados.

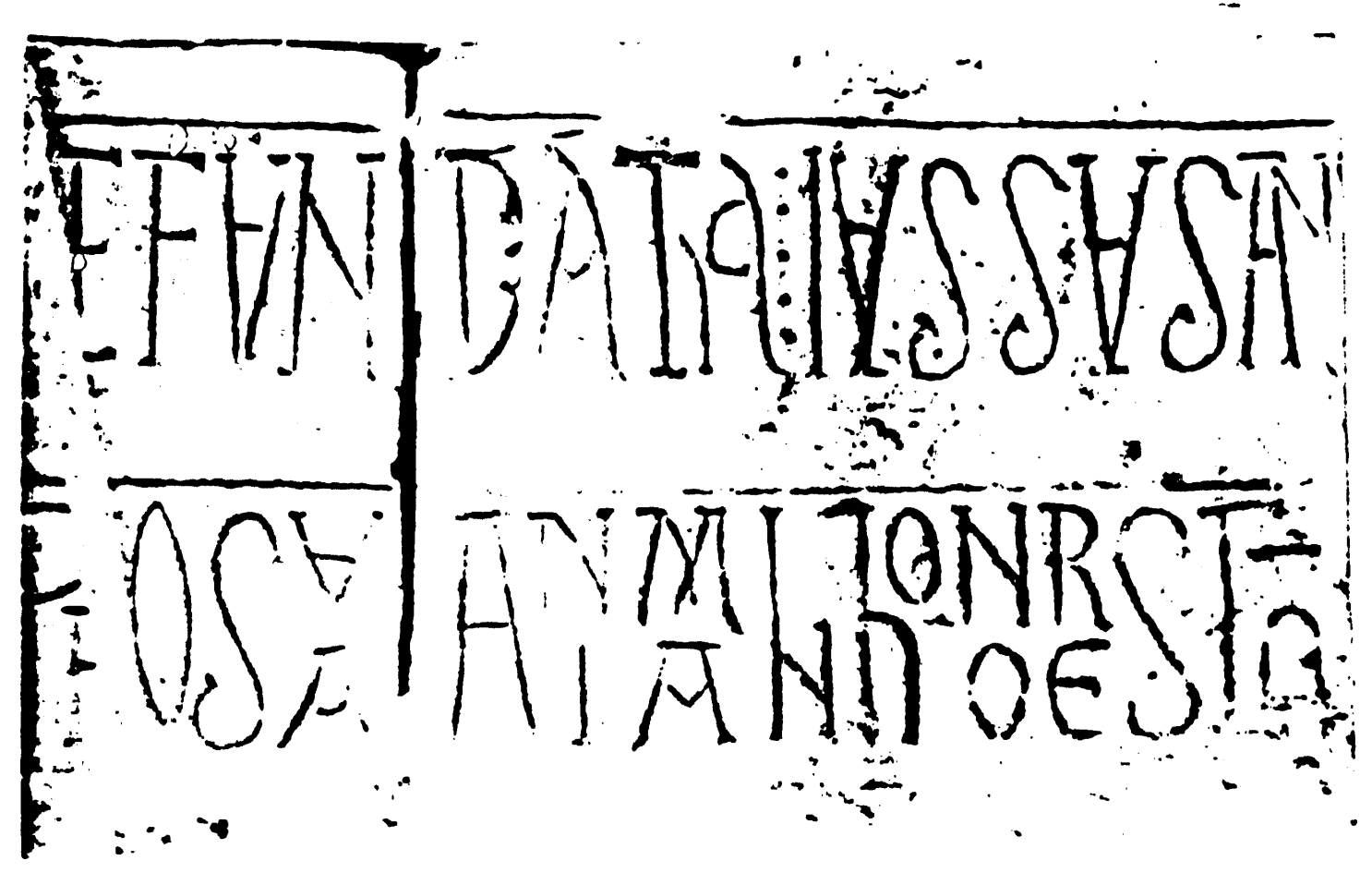

IGUACEL, año 1072 


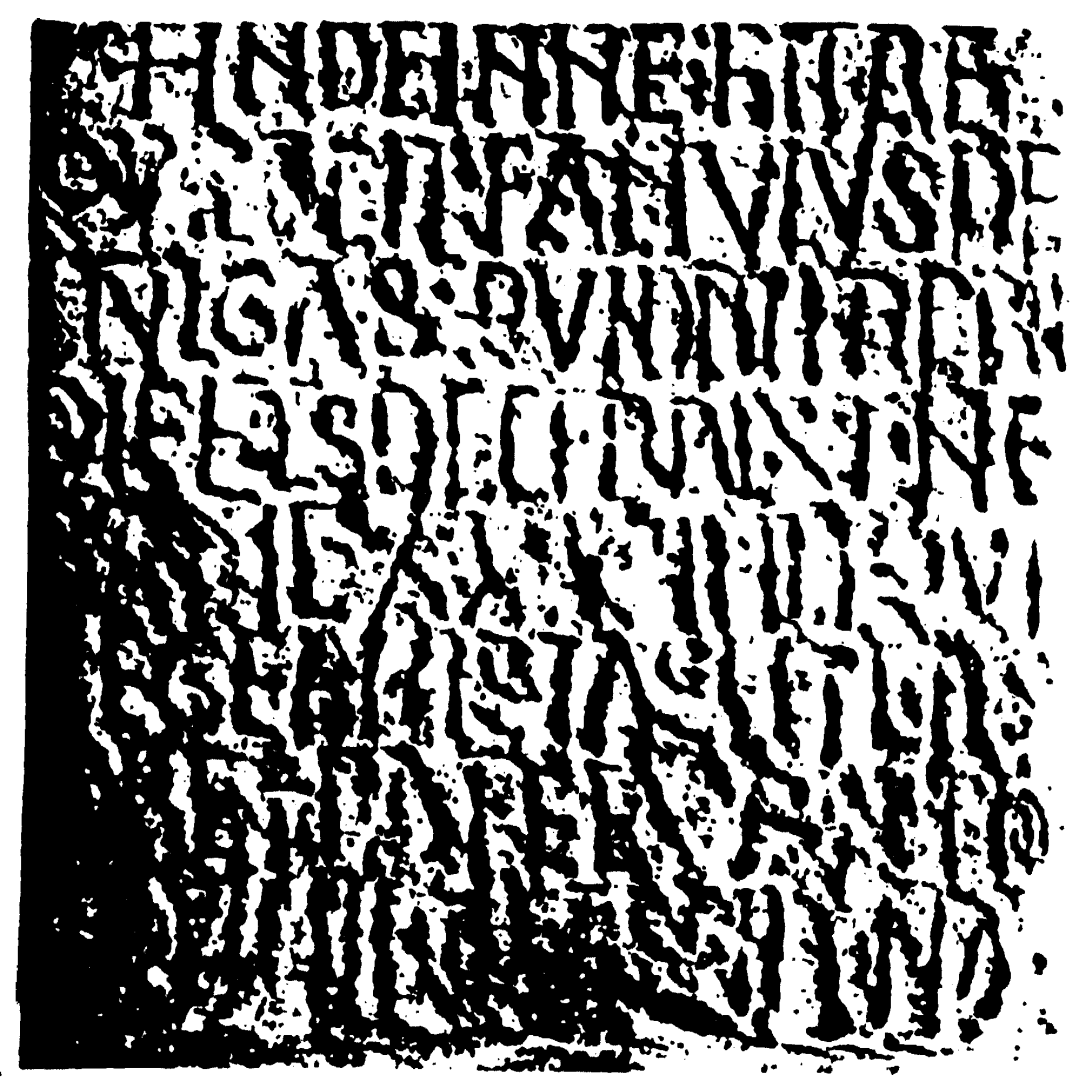

LOARRE, año 1095

Las grafías visigóticas sentadas mantienen las características habituales en otras zonas hispanas. En los siglos VIII-IX: tamaño reducido, tipos espesos y pesados, más anchos que altos, mala separación de palabras, remate inferior de $b, m, n$, vuelto a la izquierda y ausencia del uso del nexo $t j$ sibilante. En los siglos IX-X: mayor tamaño, disminuye la pastosidad, aparecen astiles fusiformes, letras más altas que anchas, mejor separación entre palabras, vuelta hacia la derecha de los remates finales de $h, m, n$, uso del; para las terminaciones - $u s$, - ue. En los siglos X-XI: trazo regularizado y fino, esbeltez, corchetes en los astiles, $I$ alta inicial y con valor sonante, generalización del nexo $t j$ sibilante, signo general abreviativo de punto sobre guión y una especie de $s$ para los finales -us, -ue. Finalmente en los siglos XI-XII apuntan ya los resabios carolinos, especialmente en la vocal $a$, uso de letras sobrepuestas o el típico signo carolino para el final -us en forma de 9.

Estudiar prácticamente estas características exige acopio de muestras en códices y en documentos.

Pero las muestras de códices son escasas: la diáspora de manuscritos ha sido muy fuerte en la zona de Aragón y no extraña hallar, por ejemplo en 
Roma, un BEATO de la colección Corsini de principios del siglo XII, o un De bello civili de LUCANO, en la colección Ottoboniana del Vaticano, de los siglos XI y XII.

Esta muestra tan parca, conocida ya por muchos manuales de Paleografía, hay posibilidades de completarla: ante todo con algunas piezas visigóticas aragonesas conservadas en su territorio: tal el Antifonario mozárabe procedente de San Juan de la Peña: se trata de un prosario e himnario del siglo X-XI del que se está preparando una importante edición crítica, y que sin duda refleja influencias castellanas; tal el Cartulario de dicho monasterio de San Juan, cuya parte visigótica parece data de hacia 1090.

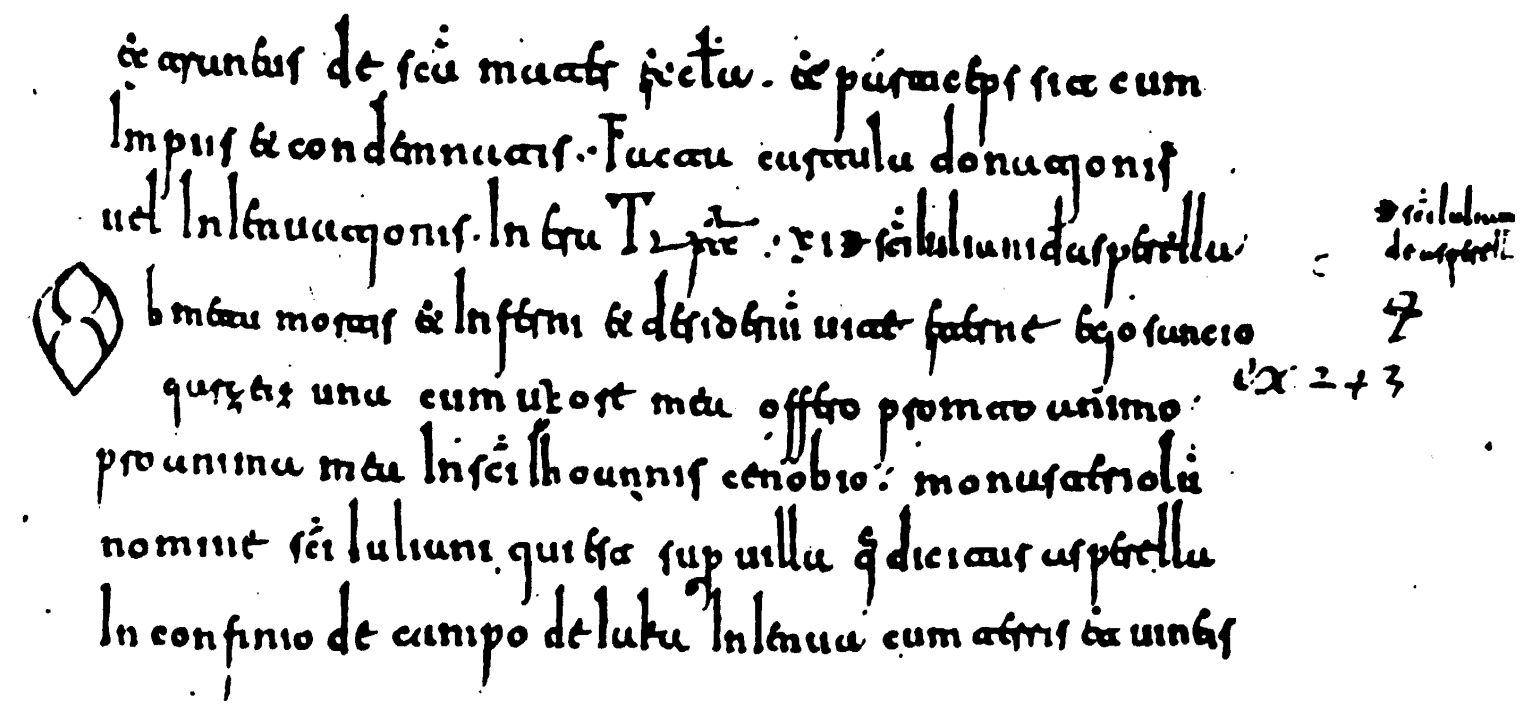

San Juan de la Peña, Cartulario, hacia año 1090.

Al mismo escritorio pertenece sin duda la llamada Biblia de San Juan de la Peña, con grafía visigótica sentada de los siglos X-XI, hoy en la Biblioteca Nacional de Madrid. Y también de área pirenaica, aunque menos conocido, es un fragmento de dos folios, tal vez de principios del siglo $\mathrm{X}$, con actas de las santas Ágata y Dorotea, hoy en una biblioteca particular zaragozana.

Esta penuria sin duda puede superarse recurriendo a las colecciones de «membra disiecta» frecuentes en depósitos de archivos, o en aplicación a encuadernaciones: desgraciadamente para Aragón son pocos los testimonios hasta ahora útiles. En estas notas presentamos a título de ejemplo algunas reproducciones de membra disiecta, procedentes de depósitos aragoneses, principalmente de origen oscense; de momento se carece de elementos para precisar la procedencia y la cronología exacta. 
Atribuible al siglo IX aragonés son los fragmentos del Commentarium in epistolam Iohannis ad parthos, de AUGUSTINUS:

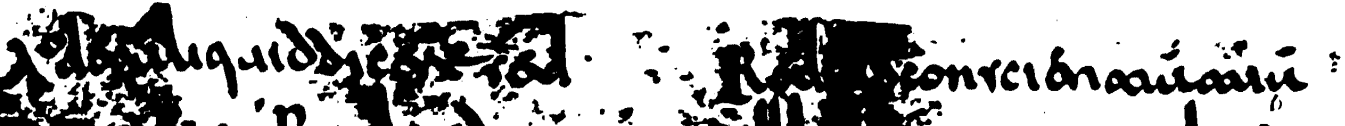

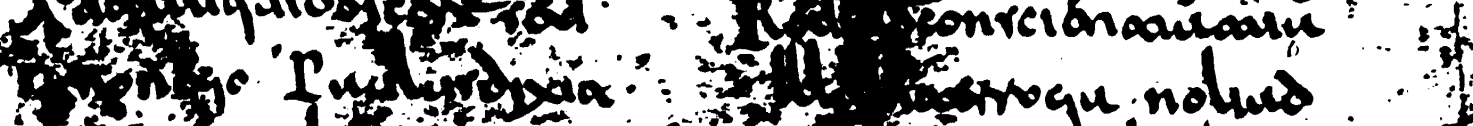

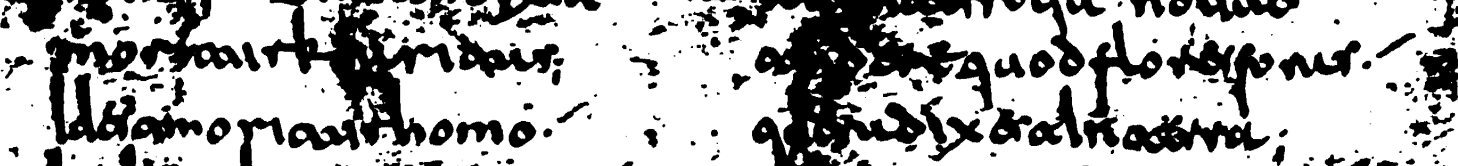

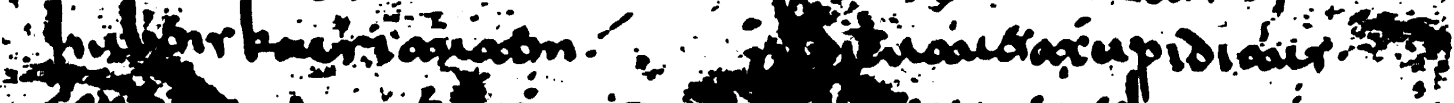

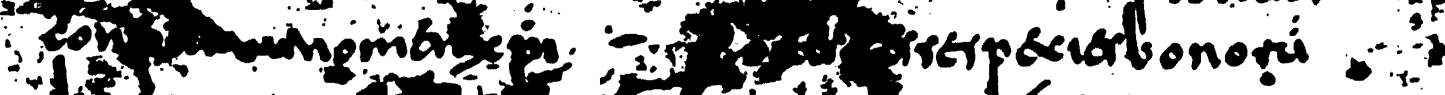

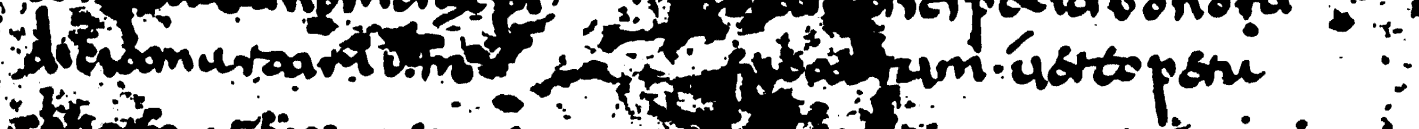

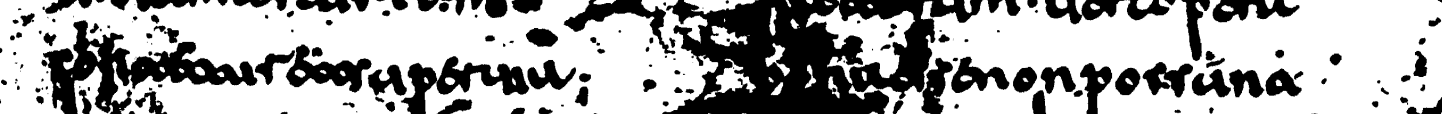

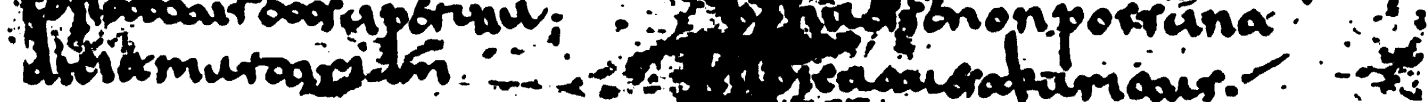

y del siglo X, otros fragmentos de CASSIANI, Collationes (Danielis, Serapioni):

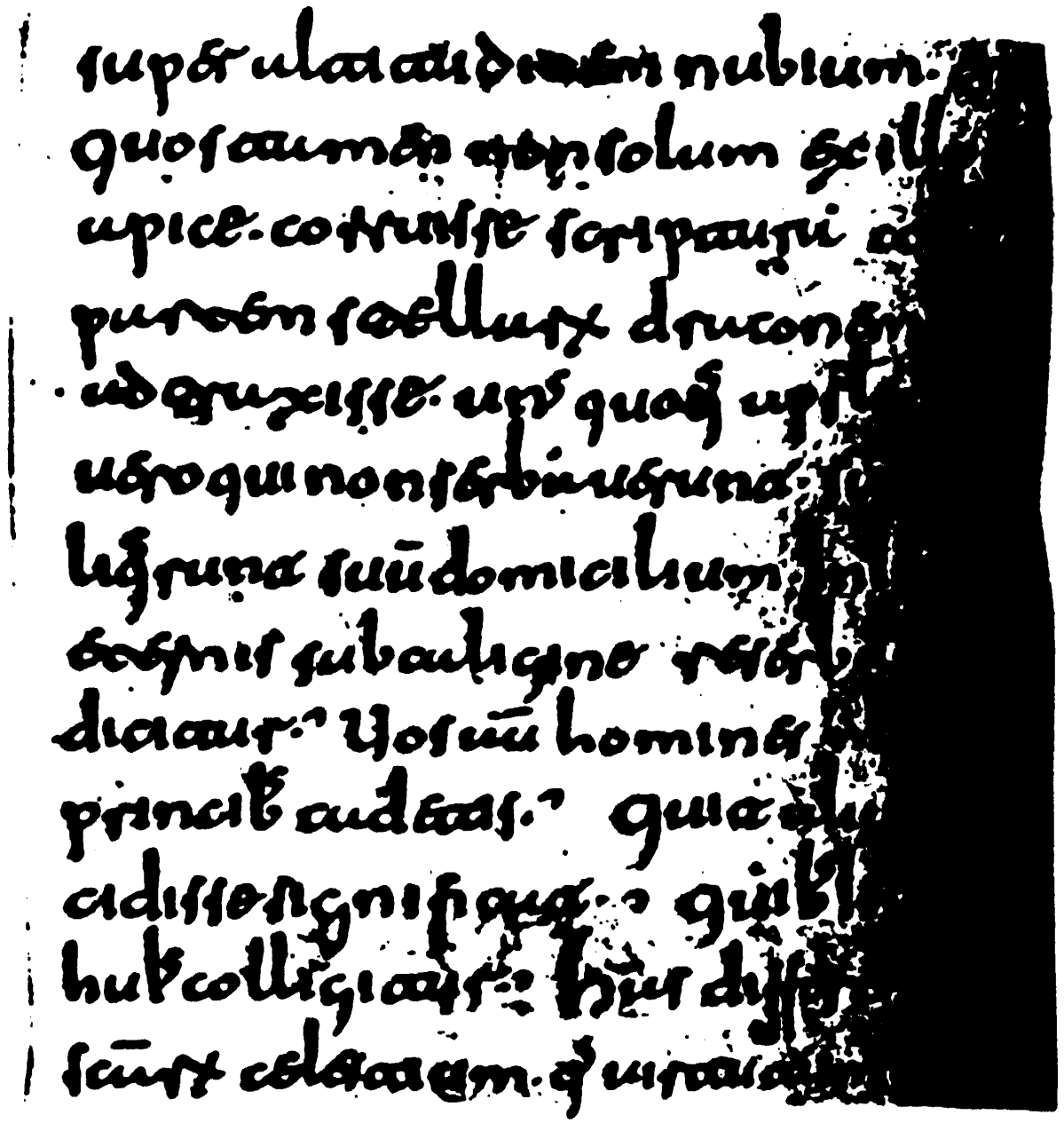


Quedan varios fragmentos de manuscritos del siglo X-XI. Por ejemplo, un ejemplar muy cuidado de un BEATUS, In apocalypsim, con muestra de caligrafía capital y uncial en sus titulaciones, sin distinción de $t j$ sibilante, etc.:

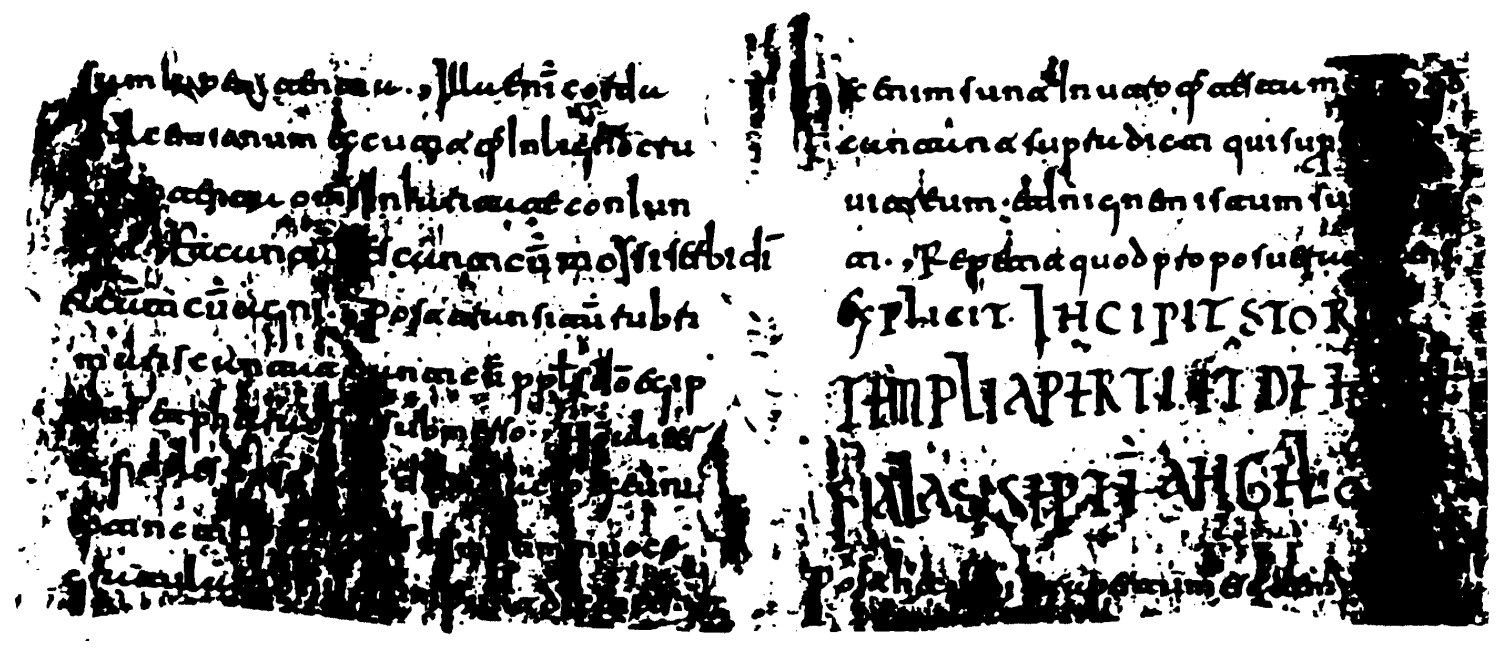

y un ejemplar coetáneo del anterior, de excelente ductus, de unos Moralia in Job de GRT:GORIUS:

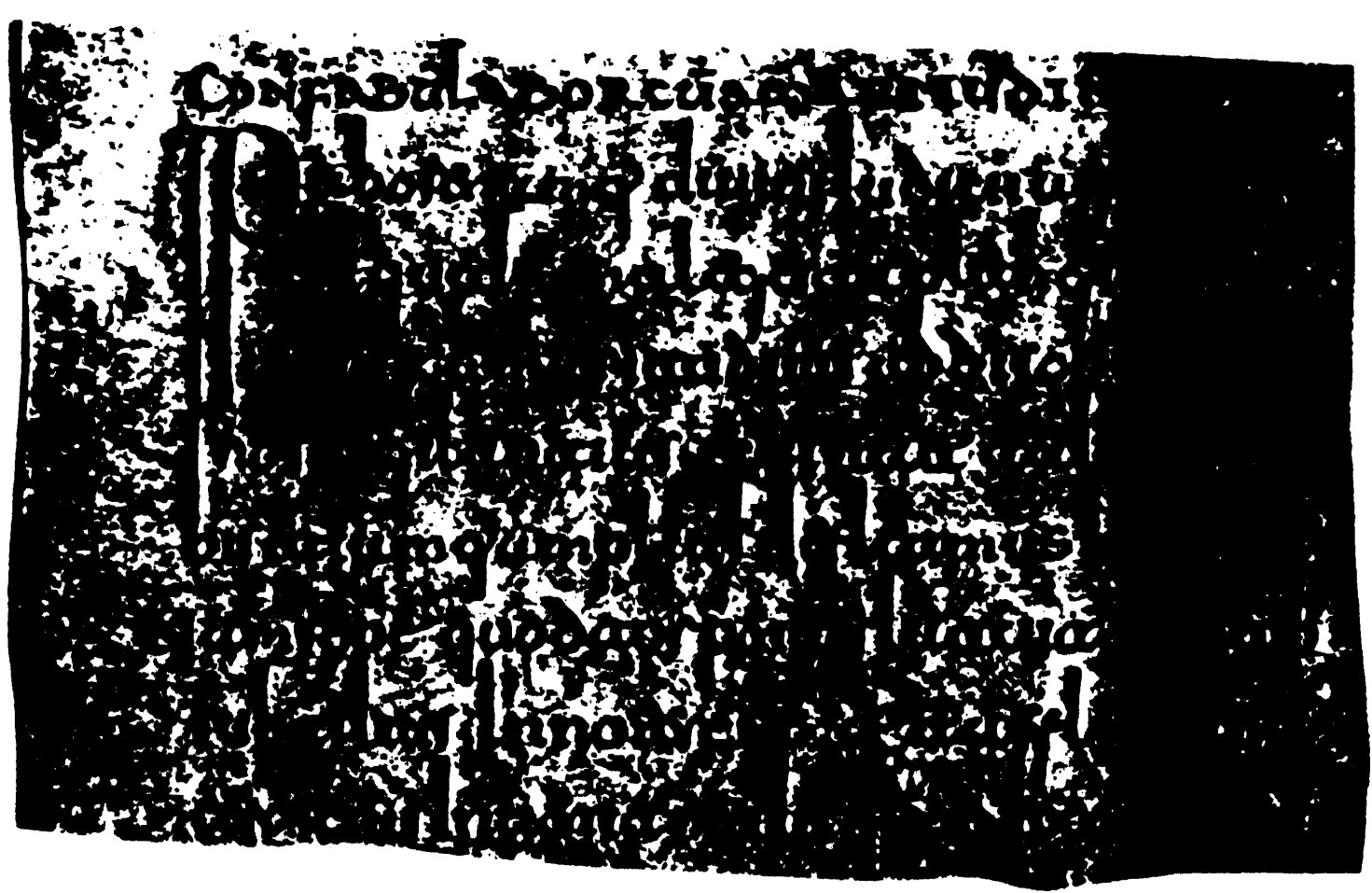


que difieren de otros fragmentos de unas Collationes CASSIANI (abbas Sereni) de ductus más esbelto, al estilo de las producciones castellanas:

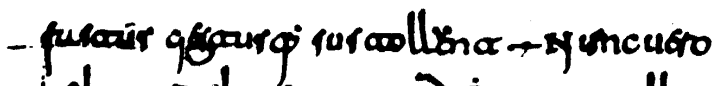

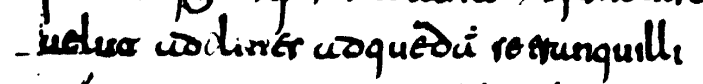
Char, raucoum cimuner blundorp

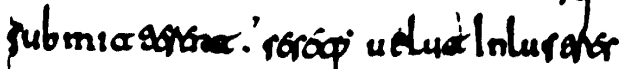
axcitim spocaunatr omits geamunat. . -jone quitoen woo rupte repotracuat rub ! smioter. cppoomr Inflgeonemonreru

Nrat. quinpthanm.ónockncaury: quipilor:

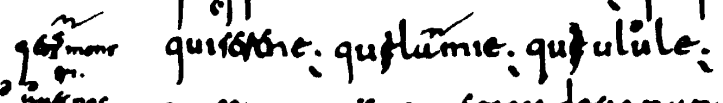
quirapuagonor: qui aricil derignunure: quicurpir: quiburilireur. Inprulmo: quilos: quidruso: quine reopprus ln eucungelio nuncupucaur: quiprincepr

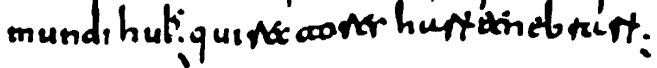

Por último, un ejemplar de visigótica sentada del siglo XI, también de procedencia pirenaica aragonesa, ofrecen fragmentos de unas Etymologiae ISIDORI, escritas a doble columna; muestra de una de ellas es ésta:

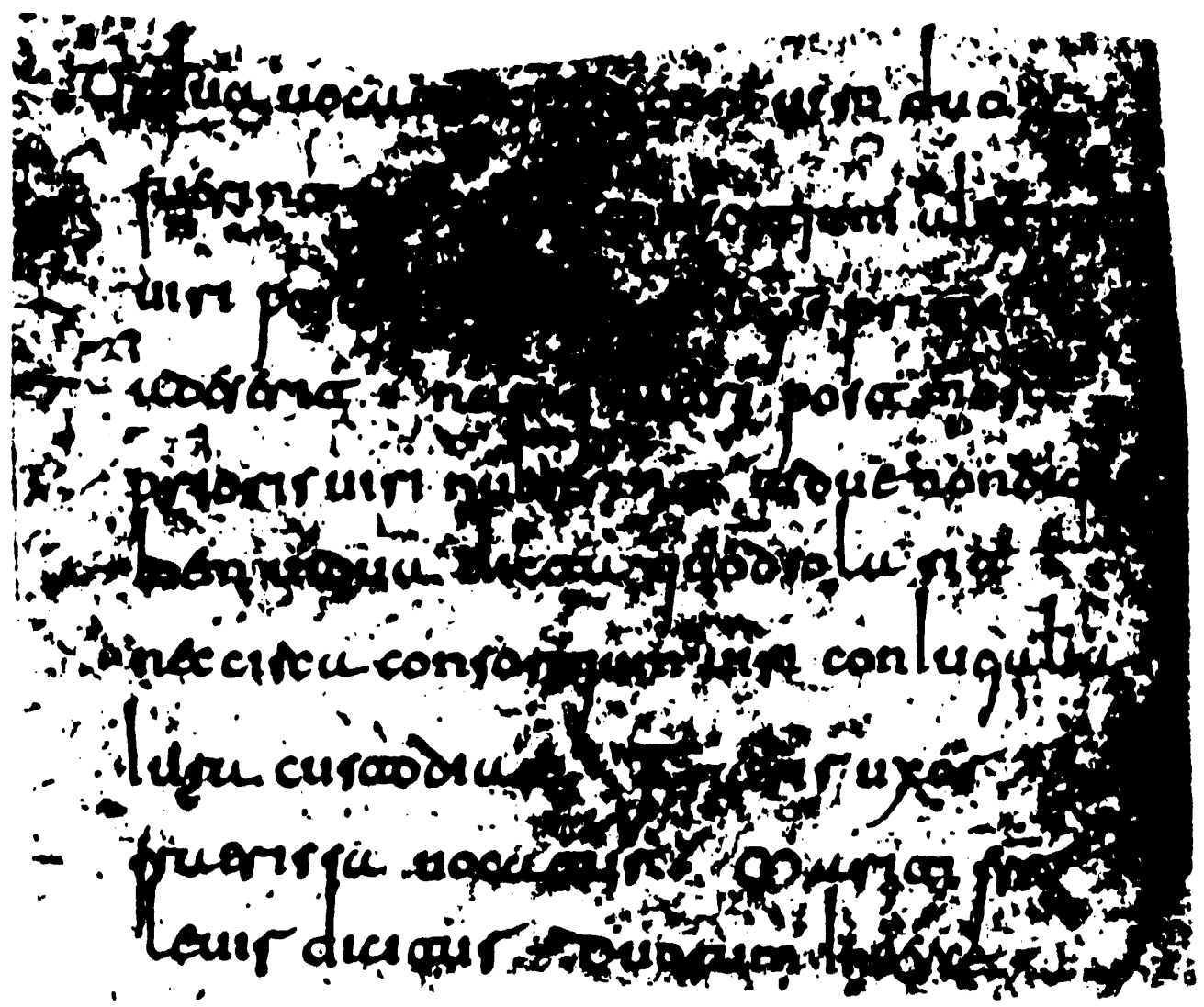


La escritura visigótica redonda es también la preferida de las cancillerías y escritorios aragoneses anteriores a la Unión con el condado de Barcelona. Se trata de grafías muy conocidas por la relativa abundancia de documentos conservados, tanto reales como privados. Los ejemplares de cancillería real de Ramiro I (1035-1063) usan visigótica sentada pura, sin elementos extraños. Véase este ejemplo de documento original conservado en el archivo municipal de Huesca, del año 1048, donde se reproducen los cinco primeros renglones y el crismón que los encabeza:

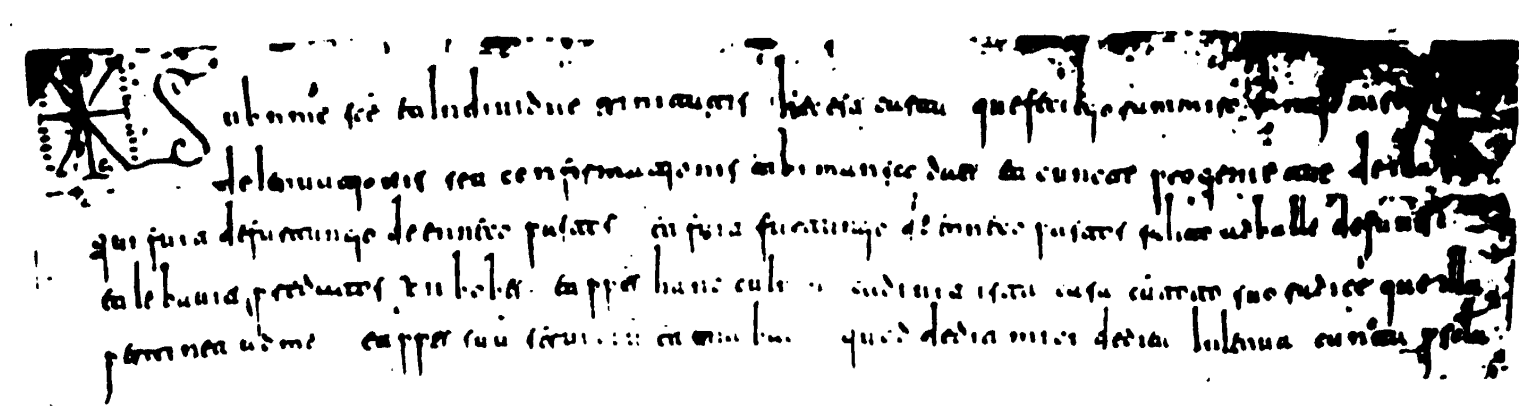

La abundancia de documentos originales de los reyes privativos de Aragón permite seguir de cerca la persistencia de la escritura minúscula sentada en las cancillerías de Sancho Ramírez (1063-1095), muy semejante a la de su padre y predecesor; buen ejemplo este fragmento de un original conservado en Barcelona, Archivo de la Corona de Aragón, datado en 1075, libre de influencias carolinas, distinción del $t j$ sibilante, escrito por Sancho Porco:

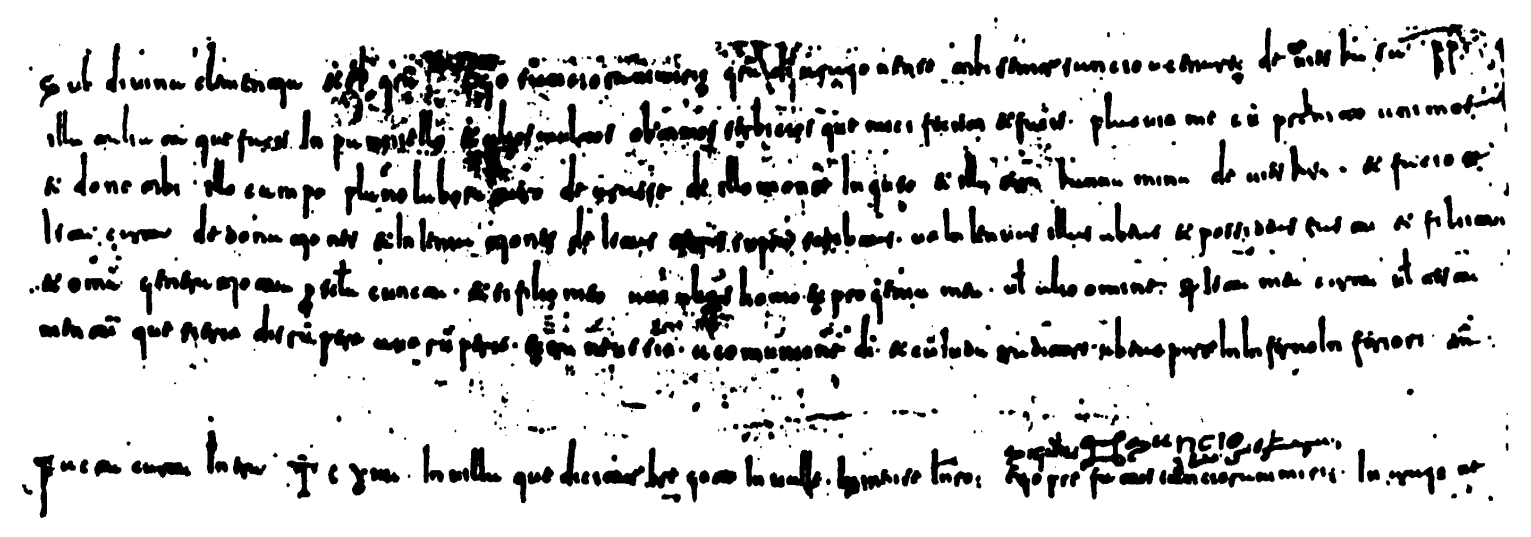

Características que se perpetúan en los documentos de su hijo y sucesor Pedro I (1094-1104), por ejemplo este fragmento del protocolo de un documento del escriba Sancho (abril de 1099), procedente del fondo de San Juan de la Peña: 


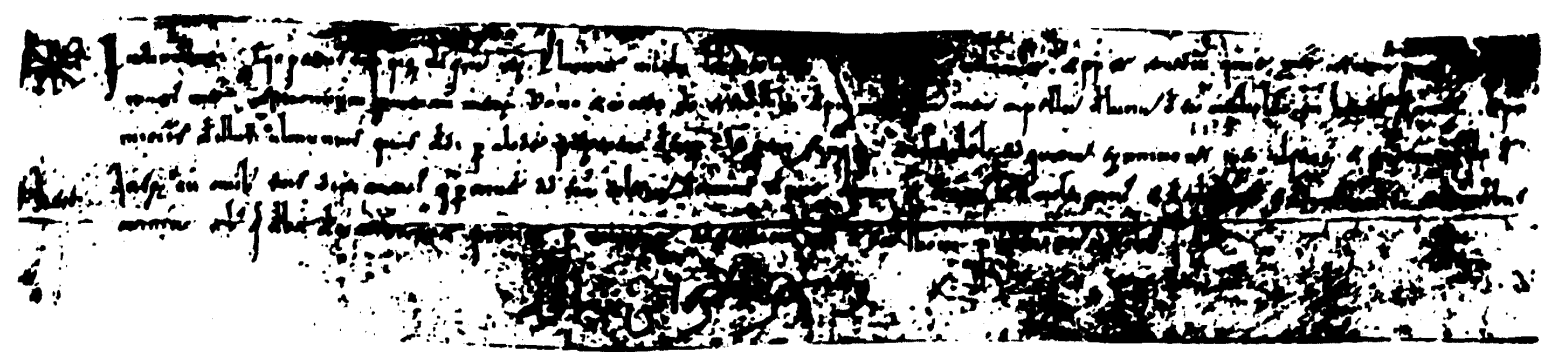

Con Alfonso I el Batallador (1104-1134) las grafías visigóticas parecen adquirir cierta angulosidad y se observan algunos influjos de la escritura carolina, como el uso de $t$ carolina en los nexos con $c, t$, anteriores, uso del signo 9 para final -us, la abreviatura de pro, alguna letra sobrepuesta, etc. Una muestra del ductus tradicional, ya impregnado de elementos carolinos, se observa en este documento de agosto de 1107, hoy conservado en el archivo de la catedral de Pamplona y del que se reproduce el escatocolo:

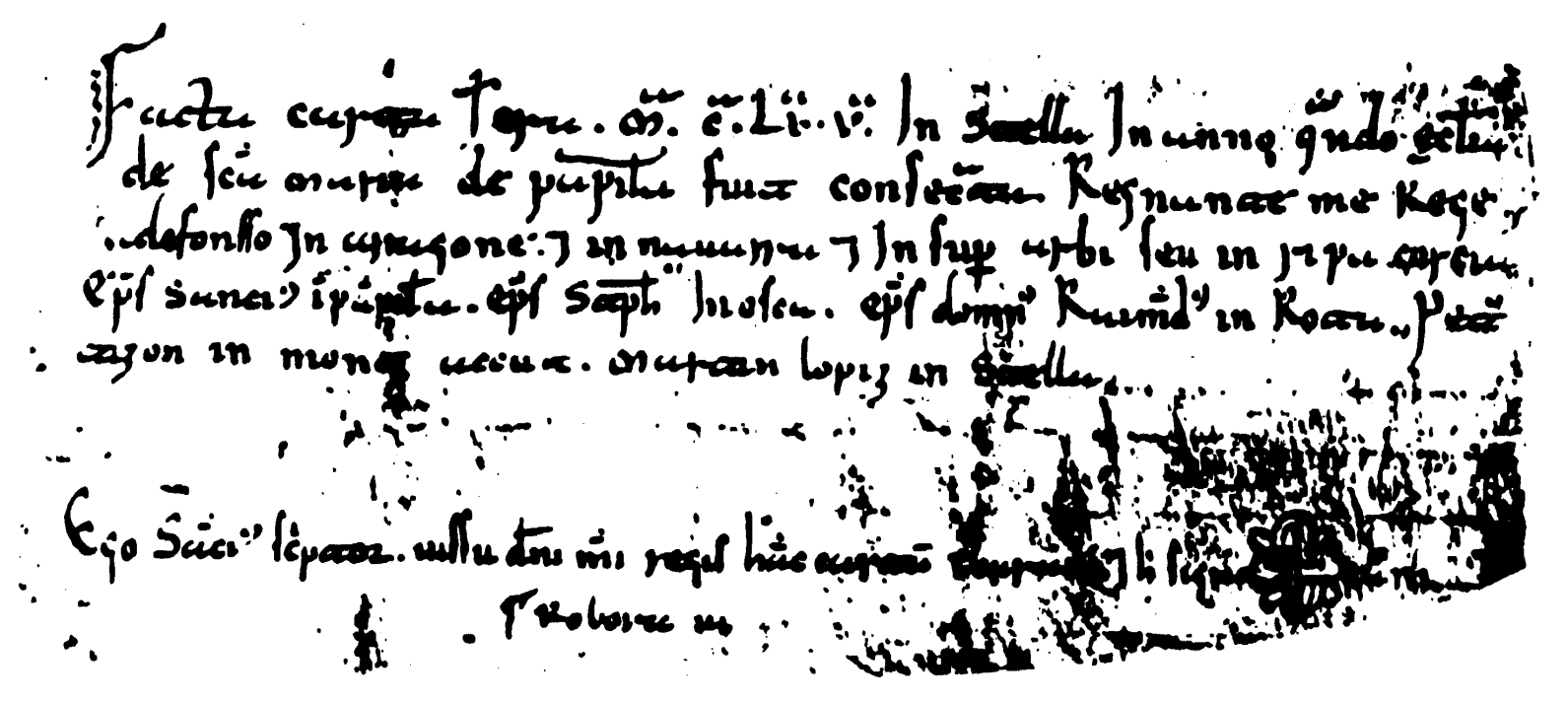

Tendencia que se acentúa en los documentos de Ramiro II (1134-1137) hasta su abdicación en Petronila, como se observa en este documento original de diciembre de 1135 que reproducimos íntegro: 


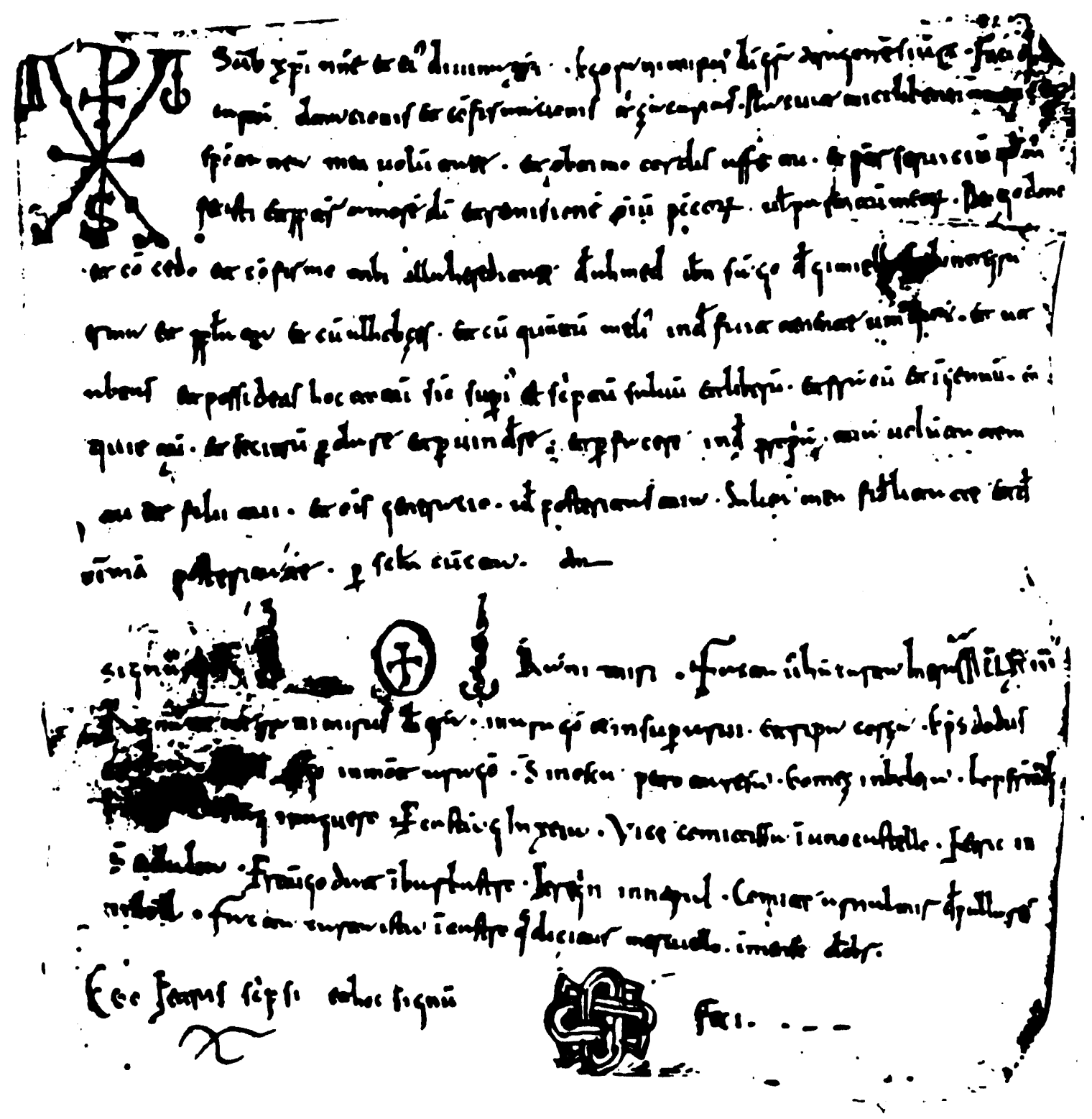

Ramon Berenguer IV conde de Barcelona, príncipe de Aragón desde 1137, mantendrá respetuosamente las costumbres cancillerescas aragonesas y sus grafías visigóticas redondas con influencias carolinas, cada vez más acentuadas, en contraste con las grafías totalmente carolinas de su cancillería condal barcelonesa. Una muestra ofrecen estos renglones iniciales del protocolo de un documento de junio de 1139, que aunque extendido en Barcelona, respeta escrupulosamente los modos paleográficos aragoneses: 


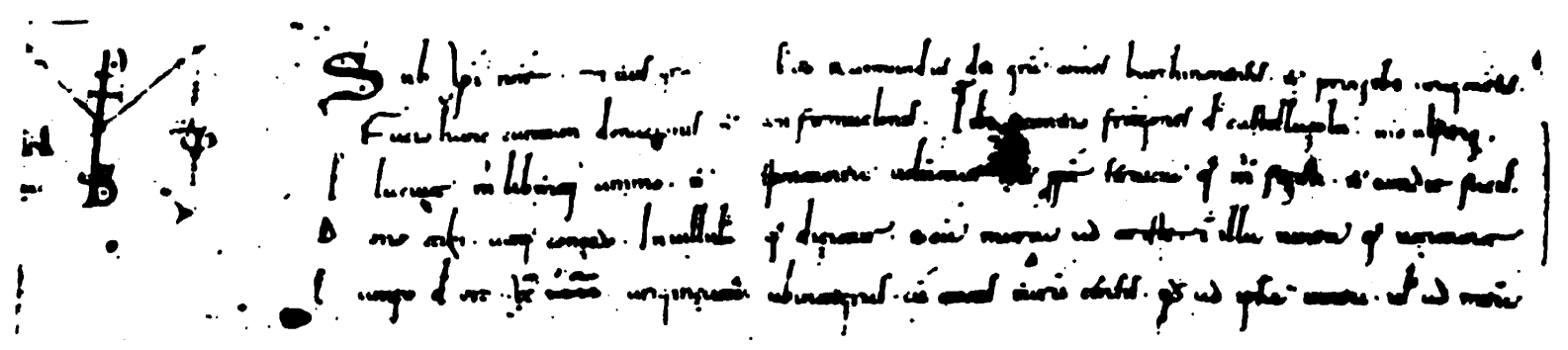

Las grafías de los documentos privados aragoneses de estos años (10351137) siguen la misma evolución de los escribas de cancillería real y no es necesario aducir muestras gráficas, muy abundantes en los archivos.

Es propio del reino de Aragón el desuso de las grafías visigóticas cursivas, relegado a glosas incidentales en márgenes de algunos manuscritos: ejemplo, las correcciones en algunos folios del manuscrito, hoy Vaticano reginense 1024, de procedencia aragonesa, escrito su texto en tipos semiunciales a fines del siglo VIII o principios del IX.

Creo que es oportuno, siempre que se analiza la paleografía de un periodo, atender a los datos de sus posibles iluminaciones.

No está estudiada a fondo la aportacion a la historia de la miniatura de los manuscritos aragoneses. En la parte central del territorio (zona de Jaca y San Juan de la Peña) se debieron iluminar el Antifonario ya citado antes (conocido vulgarmente por Libro de San Voto), que incluye el oficio de los mártires de Calahorra, desconocido en antifonarios castellanos y leoneses e interesante por sus iniciales mozárabes.

La filiación de las miniaturas de las actas del concilio de Jaca de 1063 (ejemplar de la catedral de Huesca) está sometida a revisión.

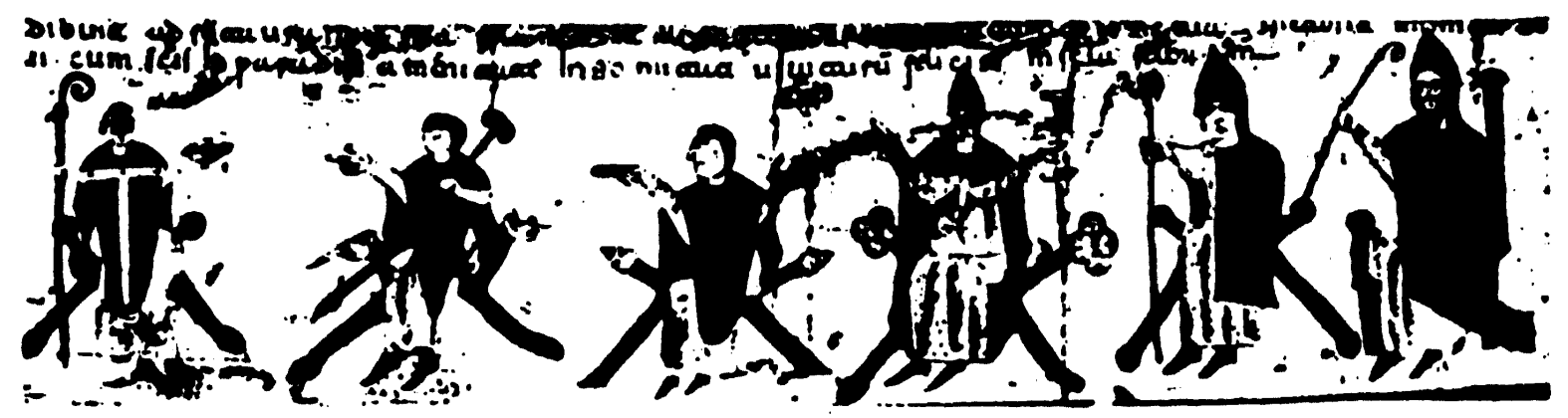


Muy interesantes son las dos figuras iniciales de estas actas, de estructura mozárabe:

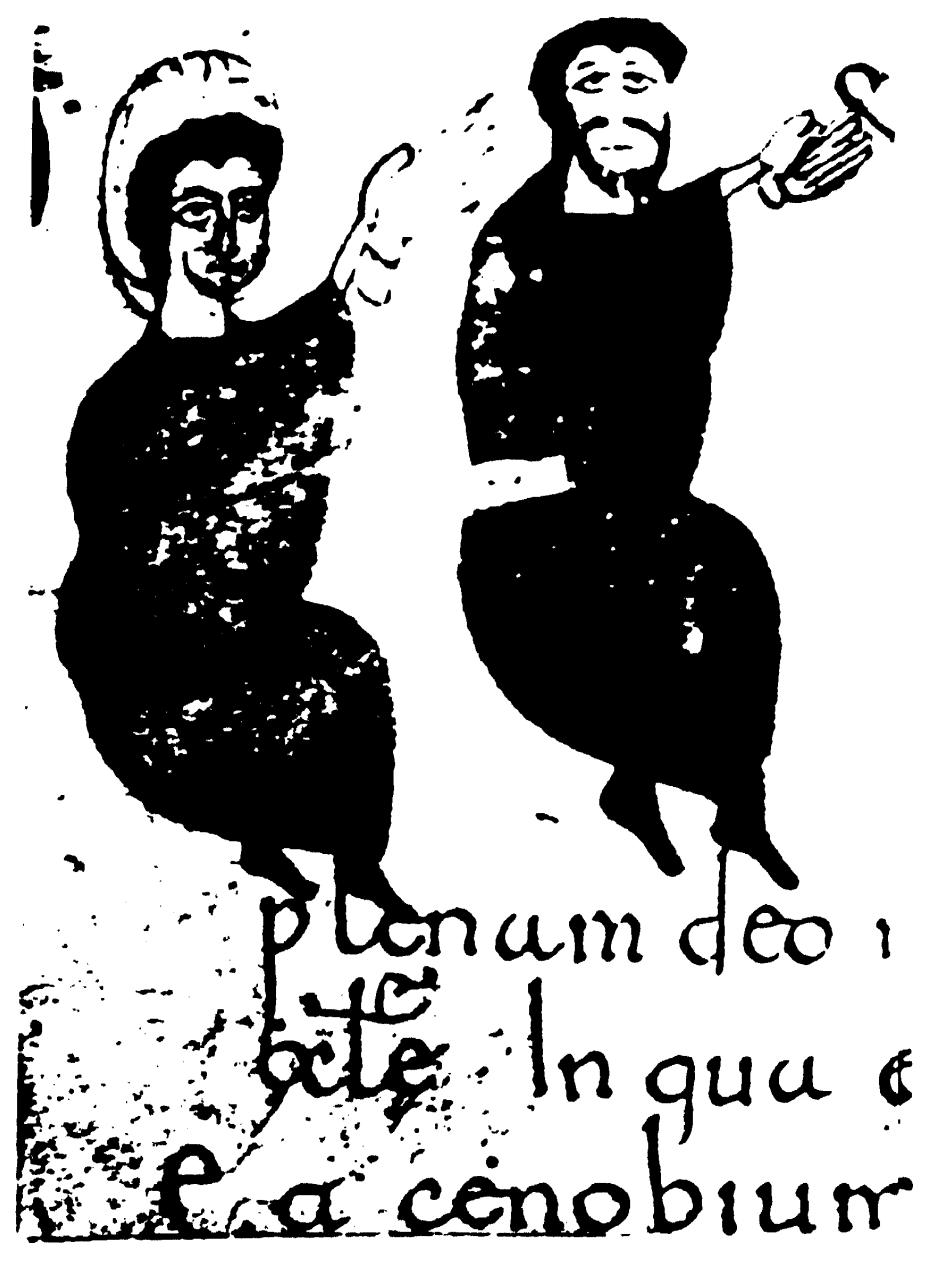

Una copia de hacia el año 1100 de estas actas, conservada en la catedral de Jaca, tiene interesantes iluminaciones de estilo linear: 


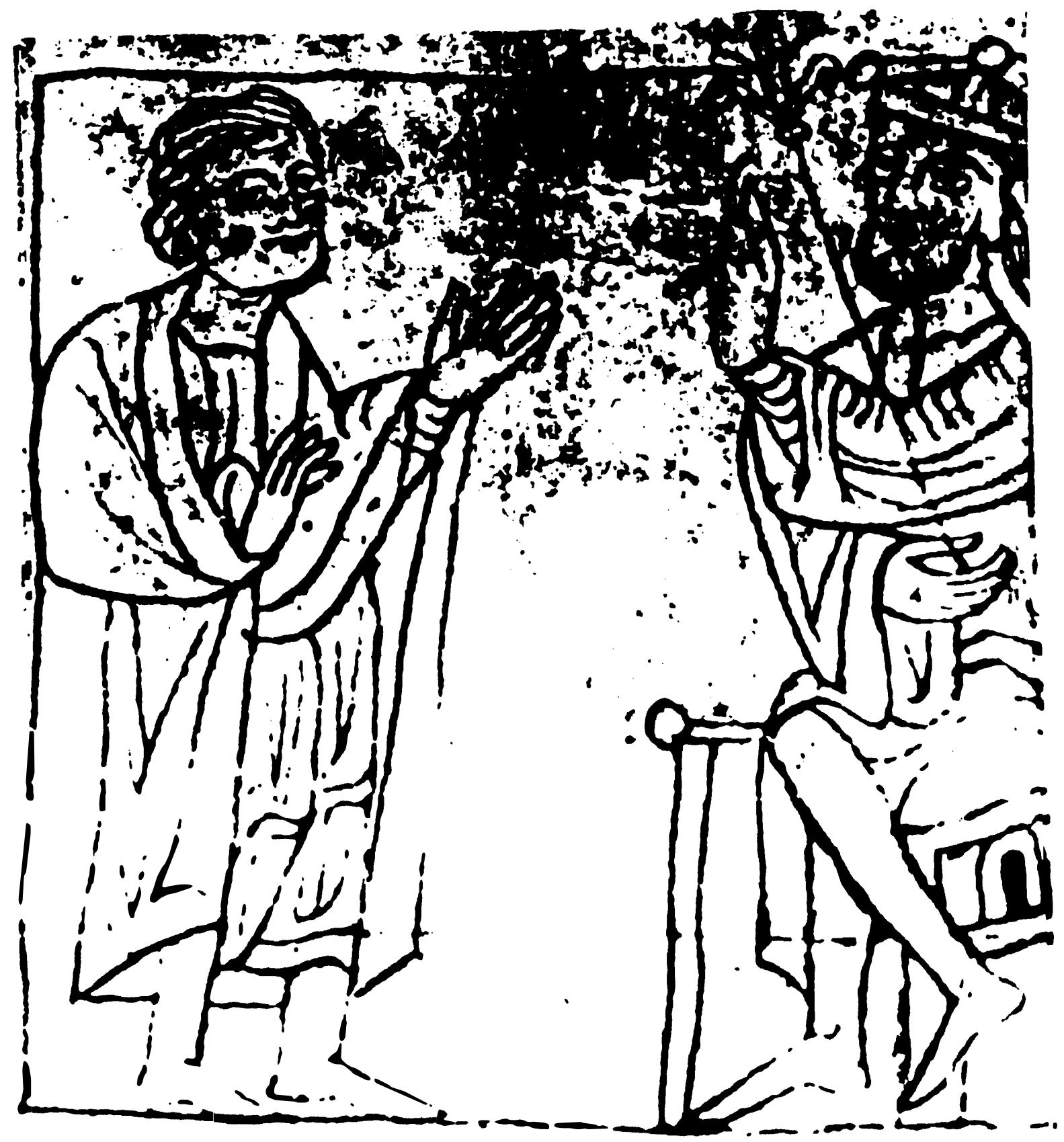

En la parte oriental, zona de Roda de Isábena, apenas hay decoración en sus manuscritos, que, por lo demás, en sus grafías indican ya influencias carolinas. 
Apenas quedan años en la paleografía aragonesa anterior a 1137, para enclavar muestras de escrituras carolinas puras. Algunos de estos testimonios serán de inmediato enumerados en las notas relativas a la iluminación de códices y documentos aragoneses carolinos.

En el mosaico de tierras llamado Aragón, la zona oriental o de Ribagorza recibe tempranamente la escritura carolina, que viene de los territorios vecinos de Pallars y Francia. Es el caso del escritorio de Roda de Isábena, donde se escribe un Ceremonial de obispos, ya a finales del siglo X, en tipos carolinos. Se han señalado con circulitos los elementos paleográficos de mayor interés, incluida la abreviatura q.s=quesumus.

$$
\dot{j} ;
$$

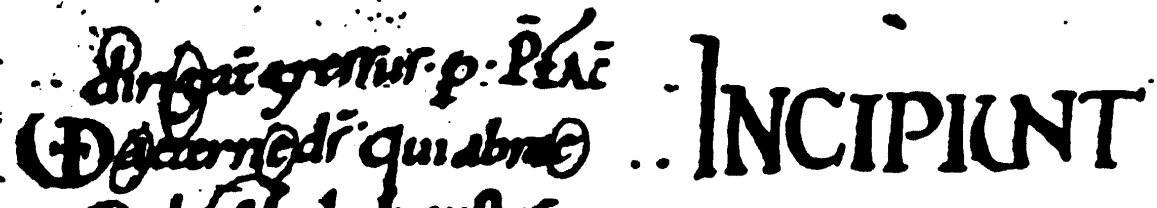

- sideslachob anim. degrofoiner aruder BENEDICGO a.elrobifarmuloras. tomaniduce pratum

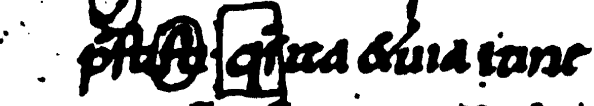

rerniricosy inicotions bur afiegensaluar pror perrace dignapedars NES.INPRIMS BEEEB]EIOIN (]GLAN

$\therefore$ parma dy $\therefore$ uremorishas

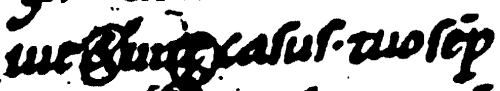
Apezandingeleoppoin Osumebar incosi.

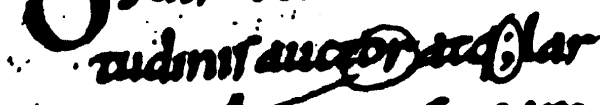

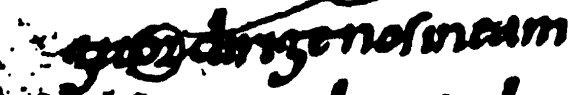

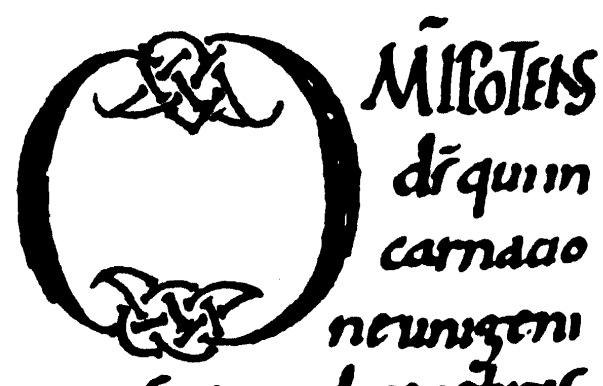
tóínmacula ambu is

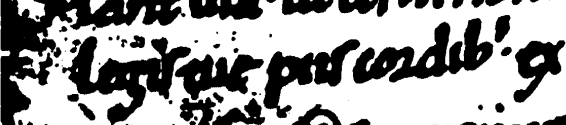
- qun proverions

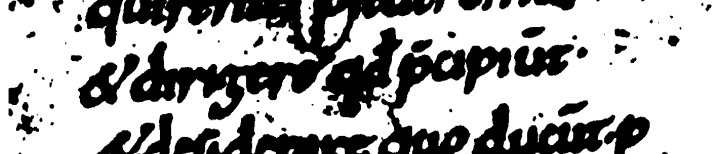

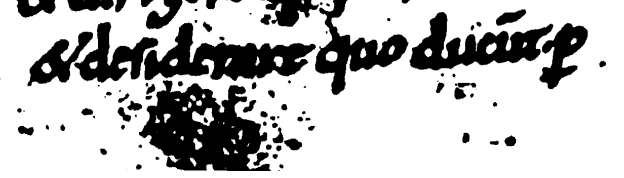
afurmunderencorar offuzaure ofaur gtora

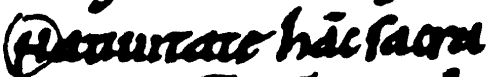

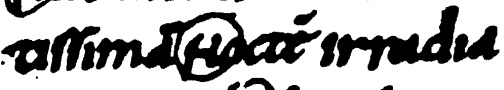

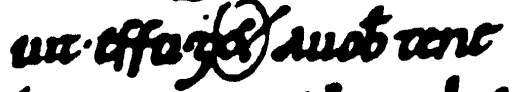

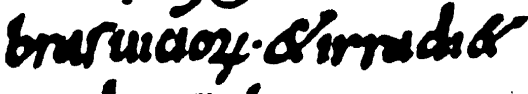
cosda uñu luce urrat wiñm Q eweq; a: 
De territorio aragonés inmediato a San Juan de la Peña son otros manuscritos, escritos probablemente en las postrimerias del siglo XI y comienzos del XII. ejemplo un SALuSTIUS, De hello iugurthino:

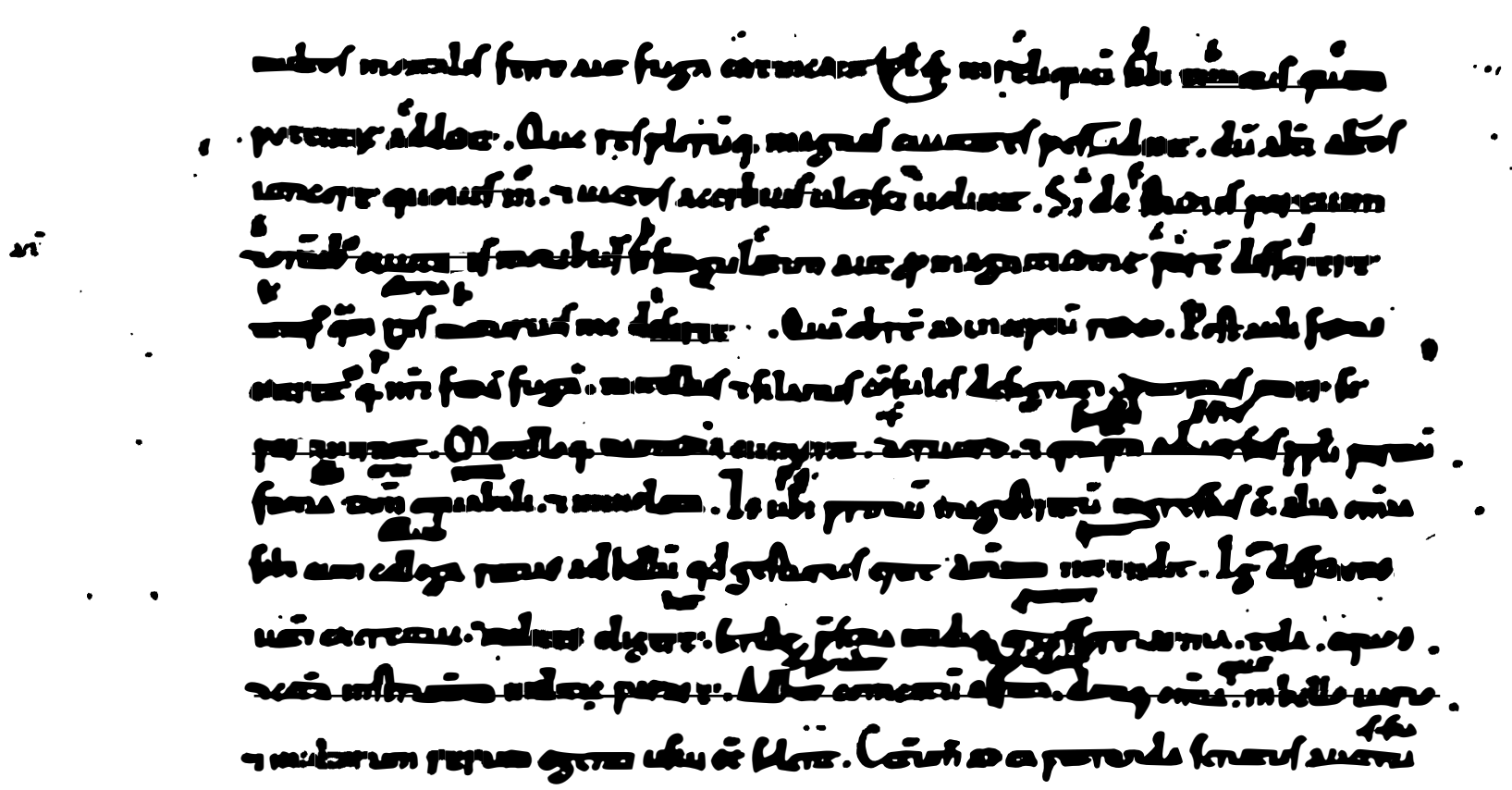

En membra disiecta recogidos en la región de Jacia, desgraciadamente sin datos precisos cronológicos, se observa la rápida implantación de escritura carolina y su evolución paulatina a las pregóticas, que se observa a mitad del siglo XII, fuera ya de la cronología que ciñe estas notas. En algunos de estos fragmentos, se puede también seguir la evolución de la notación musical, in campo aperto.

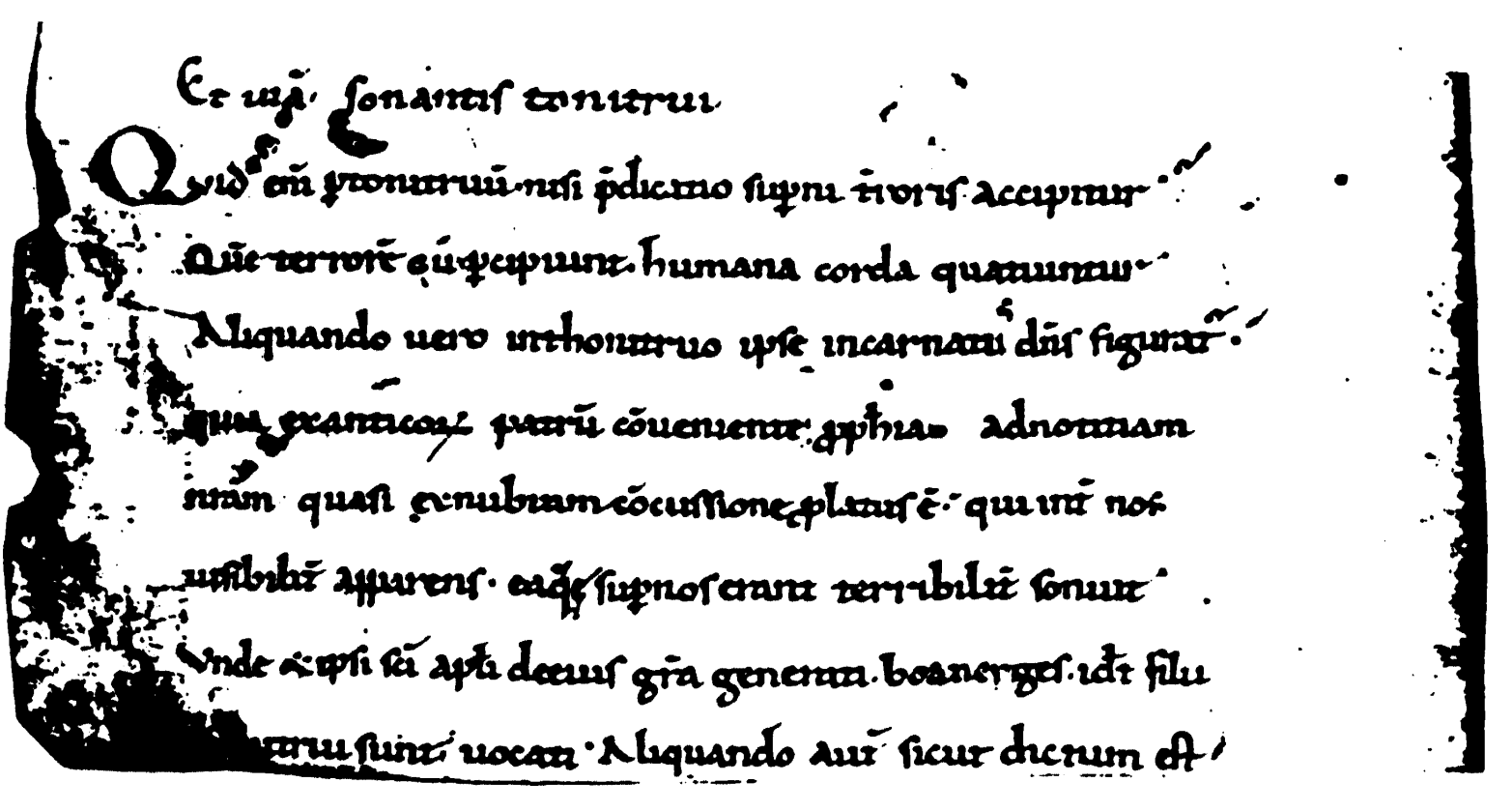



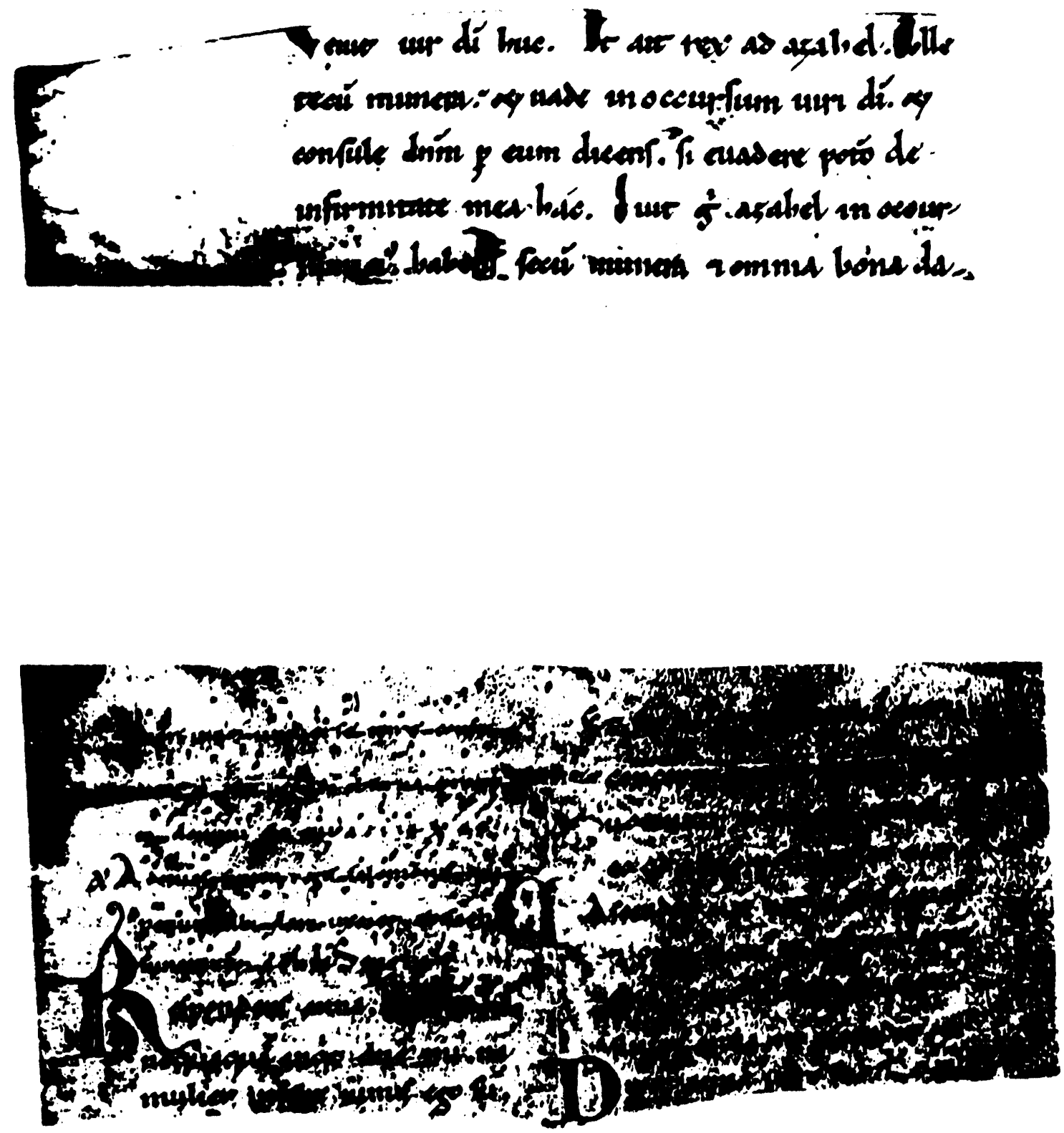
$\partial$

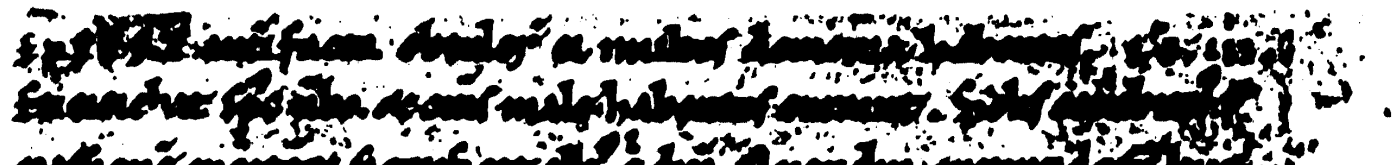
in pon

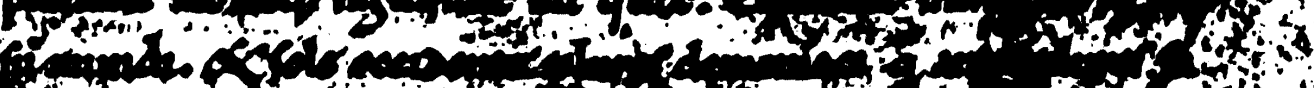

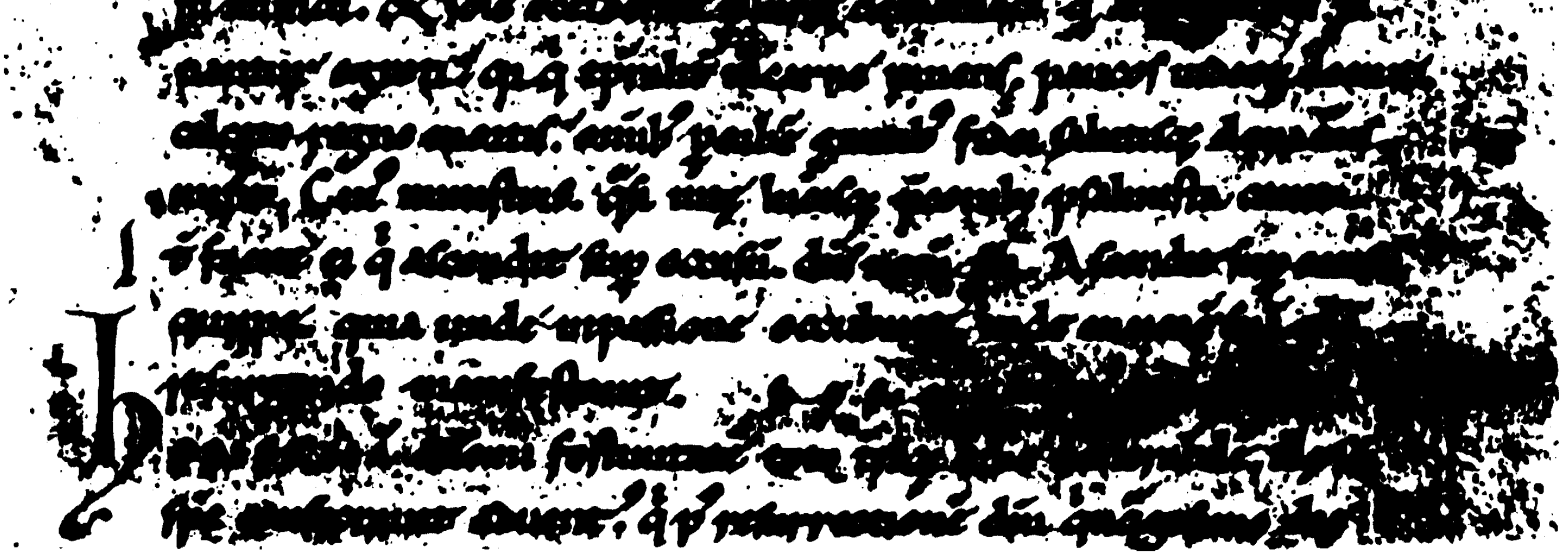




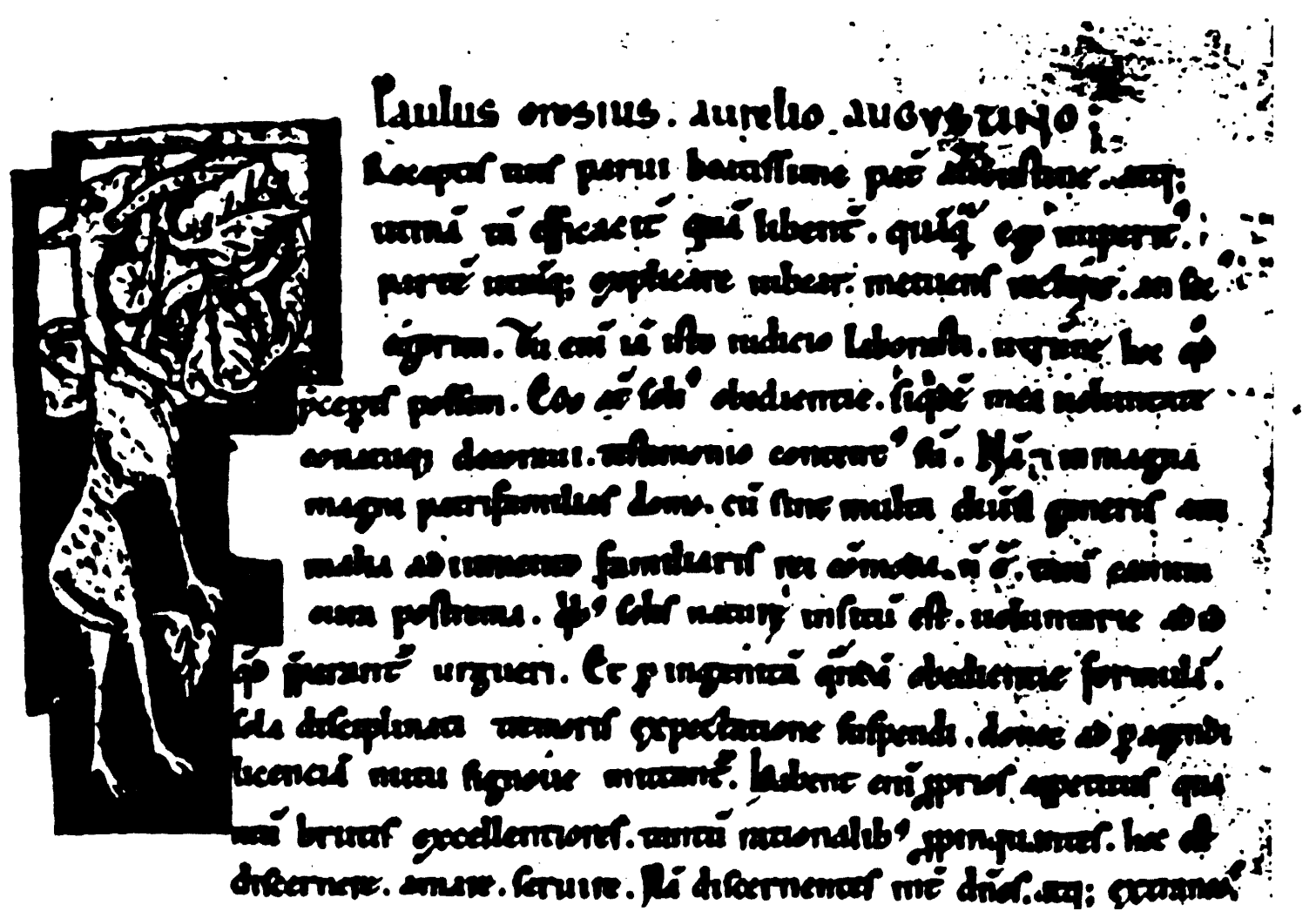

En cuanto a la implantación de las grafías carolinas en la documentación de la cancillería real y en documentos privados, el reinado de Alfonso II impone la moda al modo de lo que se venía practicando anteriormente en la cancillería condal de Barcelona, superando el respeto que su padre el príncipe Ramón Berenguer IV tuvo por la tradición visigotizante del reino aragonés de su mujer Petronila.

Cierre estas notas una breve alusión a las muestras de iluminación en manuscritos aragoneses de esta época carolina anterior al año tope 1137. En el taller de San Juan de la Peña, se observa mezclada con el arte local de temas y técnicas mozárabes la implantación de motivos carolingios europeos, como las iniciales de follajes campaniformes, los baquetones, los entrelazos, etc. De ello hay muestras en la BIBLIA A.2, hoy en la Biblioteca Nacional de Madrid, en el MISAL y el HIMNARIO, hoy en la catedral de Huesca, de los siglos XI-XII, muy semejantes en ornato a la citada Biblia pinatense.

Parece hubo en la zona oscense una escuela de miniaturas aficionada a los dibujos a pluma, que aparecen en algunos documentos: un oscense, Sancho de 
la Rosa, luego obispo de Pamplona, hará famoso el dibujo de una cabecita que emplea para signo personal autenticante de sus documentos.

En algunos de estos dibujos, las actividades de los personajes y los esquemas de los paños de sus vestes, parecen inspirados en estilo catalán coetáneo (ejemplo una donación del año 1098 de Pedro I a la catedral de Jaca).

Las iniciales zoomorfas de un OROSIUS, Contra paganos, hoy en Madrid, Biblioteca Nacional ms. 8831, obra de Guillermo y Jimeno, del siglo XII, y las muy abundantes que mezclan figuras animales con temas vegetales y alguna figura humana esbelta, con actitudes graciosas, paños adheridos al cuerpo, pliegues finos que semejan obras escultóricas, también aparecen en algunos manuscritos de procedencia aragonesa de la primera mitad del siglo XII. 


\section{BIBLIOGRAFÍA}

Solamente se mencionan monografías esenciales; para cuestiones de detalle, especialmente sobre códices concretos aquí mencionados, véase la abundante literatura reunida en MILlaRES-ASENCIO, Tratado de Paleografía Española, Madrid, 1983.

GALINDO ROMEO (Pascual), Colección diplomática de Alfonso I el Batallador, Tesis doctoral inédita, Zaragoza, 1919.

GAlindo ROMEO (Pascual), Reivindicación de documentos de Alfonso I el Batallador, Zaragoza, 1934.

USÓN SESÉ (M) y CANELlAS LÓPEZ (A), El libro gótico • cartulario de San Juan de la Peña, Zaragoza, 1935.

USÓN SESÉ (Mariano), Contribución al estudio de la cultura medieval aragonesa. La escritura en Aragón del siglo XI al XVI, Zaragoza, 1940.

Canellas López (Ángel), Colección diplomática de Sancbo Ramírez, rey de Aragón y Navarra, Tesis doctoral inédita, Madrid, 1944.

BALAGUER (Federico), Una nota sobre la introducción de la letra carolina en la cancillería aragonesa, Zaragoza, 1952.

CANellas López (Ángel), Colección diplomática de San Andrés de Fanlo, 958-1270, Zaragoza, 1964.

MARTín POSTIGo (Soterraña), Alfonso I el Batallador y Segovia, Segovia, 1967.

CANELlas LÓPEZ (Ángel), Exempla scripturarum latinarum in usum scholarum. Pars altera. Editio iterata, Zaragoza, 1974. 
CANellas LóPeZ (Ángel), El cartulario visigótico de San Juan de la Peña, Las Palmas de Gran Canaria, 1975.

ARAGÓ (A.M.) y TRENCHS ODENA (J.), Las escribanias reales catalano-aragonesas, de Ramón Berenguer IV a la minoria de Jaime I, Madrid, 1977.

CANEllas LóPEZ (Ángel), Los escritorios benedictinos, Zaragoza, 1980.

CANellas LÓPEZ (Ángel), La cancillería real del reino de Aragón (1035-1137), Zaragoza, 1982.

\section{RÉSUMÉ}

L'héritage paléographique d'Aragon, pendant le haut Moyen Age et jusqu'à son union avec le Comté de Barcelone en 1137, est très interessant pour le paléographe yui y trouve un champ d'observation sur la persistance particulière de la tradition culturelle wisigothe, qui s'est maintenue longtemps, jusqu'à l'apparition des graphies carolines. De là vient l'intérêt des exemples conservés dans les manuscrits anciens et les documents.

Le Règne d'Aragon primitif, ensemble de terres indépendantes, sont réunies par un roi qui les intègre successivement. C'est un terrain intéressant pour étudier la lente évolution des graphies wisigothes depuis le VIII ${ }^{\mathrm{cnt}}$ jusqu'au XII ${ }^{\mathrm{em}}$ siècle, moment où apparaissent les mauvaises habitudes de l'écriture caroline.

Dans cet article, on passe en revue d'interessants exemples d'écritures, conservés dans des manuscrits anciens et des documents qui illustrent cette lente évolution graphique, ainsi que des enluminures qui mèlent l'art local mozarabe a l'implantation graduelle de motifs carolingiens européens.

\section{SUMMARY}

The palaeographic legate of Aragon during the later Middle Ages till its union with the earldom of Barcelona in 1137 is most valuable for the palaeographers. He finds in it a field to observe the especial persistence of the visigothic tradition until the appearance of the caroline script. Hence, the interest of the well-preserved examples of codex and documents.

The primitive reign of Aragon, a series of parcels of land lacking solidarity, united by a king who joins them progressively, is an interesting field to study the slow evolution of the visigothic scripts since the VIII th to the XII th century, when the defects of the caroline script appeared. 
In this essay, we go through interesting specimens of scripts that show the slow graphical evolution of codex, documents and of their illuminations that mix local mozarabic art with the progressive implantation of European Carolingian motives. 